\title{
Application of Augmented Water Flooding Using Ultrasound Energy to Improve Oil Recovery
}

\author{
U. Hassan, M. B. Adamu, I. Bukar, and M. A. Muhammad
}

\begin{abstract}
The application of ultrasound energy in improving oil recovery is an emerging technique, it has been tested in laboratories and some field applications in different parts of the world. In this study, Nigerian crude oil of $4.21 \mathrm{cSt}$ viscosity and sandstone rock samples were tested using a designed and constructed experimental rig. The rig is an analogue of a standard core flooding set up and works on the principle of fluid flow in porous media. Furthermore, a modeled equation was developed to better understand the effects of power and time on the volume of oil recovered at a constant ultrasound frequency. Results obtained show a positive impact in the recovery of residual oil during waterflooding with the assisted ultrasound energy. About 2 -fold increase in the recovery of oil was observed when the ultrasound energy was applied to augment the waterflooding process. Model equations developed were found to be adequate because the adjusted and predicted $R$-squared values show reasonable agreement ( $R$ adjusted $=0.9993$, R-Predicted $=0.9974$ ) .
\end{abstract}

Index Terms - Ultrasound Energy, Oil recovery, Waterflooding, Model equations, core flood experiment, Response Surface Methodology.

\section{INTRODUCTION}

Recovering a significant volume of oil reserve is a serious challenge to the oil industry. There are many research studies on oil recovery improvement. Most approaches of improving oil recovery currently used by the oil industry have some challenges and limitations. However, several researchers have been making efforts to address those challenges and limitations [1].

After the depletion of the natural energy locked up in the reservoir, the common practice by E\&P operators to supplement the primary energy is basically pressure maintenance, which is mostly water injection or gas injection. The general practice is water is injected through injection well(s) to the production zone or gas is injected to the gas cap to push the oil to production well [1].

The economic limit of the secondary recovery is attained when the volume of the injected fluid become excess in the gross produced fluid, thus overloading the production facilities and making oil production uneconomical. Several research works have been conducted to increase oil recovery after the secondary recovery is no longer economical. Those methods used to improve oil recovery after the secondary recovery are referred to as enhanced oil recovery methods or tertiary oil recovery methods. Generally accepted enhanced oil recovery methods by Exploration and Production Companies are chemical flooding, thermal method and miscible gas method [2], [3].

Published on February 2, 2021.

U. Hassan, Abubakar Tafawa Balewa University, Nigeria.

(e-mail: shingasco@gmail.com)
Waterflooding is the most popular secondary oil recovery method because it is cheap and readily available. However, waterflooding has some drawbacks which generally affect its continuous application. Chemicals are commonly used to improve water flooding by reducing the challenges and drawbacks [3]. However, chemical flooding has some challenges which include:

1. Wellbore plugging;

2. Reservoir fluid/rock compatibility issues with injected chemicals;

3. High cost of chemicals;

4. Environmental pollution.

Because of the challenges associated with chemical and other conventional enhanced oil recovery methods; there are many researches on the use of electrical method to improve the oil recovery, and it was found to be efficient, low cost and less risk [4]. The following are some examples of electrical enhanced oil recovery method:

1. Low-frequency heating (Ohmic).

2. Inductive heating.

3. Microwave heating $(300-300,000 \mathrm{MHz})$.

4. Ultrasound waves etc. $(20-1000 \mathrm{kHz})$.

Study on the application of ultrasound energy in depleted oil wells for improved recovery of oil has been conducted by [5]. The ultrasound energy source was used as either intermittent or permanent placement. The results obtained from the work show an improvement in oil recovery by up to $50 \%$.

An experiment was conducted by [6] to study the ability of ultrasound waves to improve oil production. The experiment was conducted at original oil in place and at residual oil saturation. The results found show that; oil recovery factor is better in the case of residual oil saturation than the case of original oil in place. The setup used is displayed in Fig. 1.

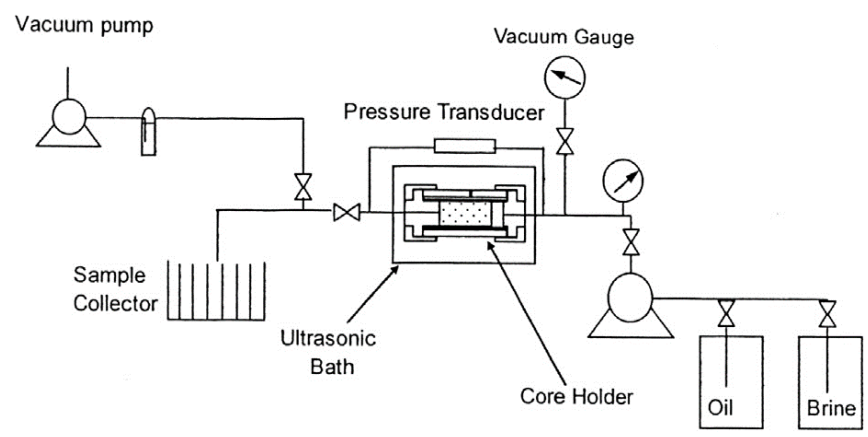

Fig. 1. Experimental setup used for ultrasound enhanced oil recovery [6].

M. B. Adamu, Abubakar Tafawa Balewa University, Nigeria.

I. Bukar, Abubakar Tafawa Balewa University, Nigeria.

M. A. Muhammad, Abubakar Tafawa Balewa University, Nigeria. 
An experiment was carried out by [7] to determine the effect of ultrasonic radiation on oil recovery. They placed an oil-saturated sandstone core sample into imbibition cells and determine oil recovery with and without ultrasonic radiation. They observed improvement in oil recovery when the ultrasonic wave was applied.

A research on the effect of high-frequency waves in improving oil recovery using glass bead pack experiment was conducted by [8] and [9]. They discovered that ultrasound energy has a positive effect on oil recovery. However, [8] concluded that sonication has a negative effect on ashaltenic (viscous) crude oil sample.

According to [10], after ultrasound stimulation was carried out on three wells, an average increase of 32.6 barrels of oil per day was observed, and the effect of the treatment on oil production was about six months. During the treatment, fluid was injected to aid wave propagation. They developed a downhole tool, PSMS-102 and was then tested in some oil fields in Western Siberia and Samara Region of Russia. Fig. 2 and 3 displayed the downhole tool developed and the ultrasonic equipment arrangement for near-wellbore treatment respectively.

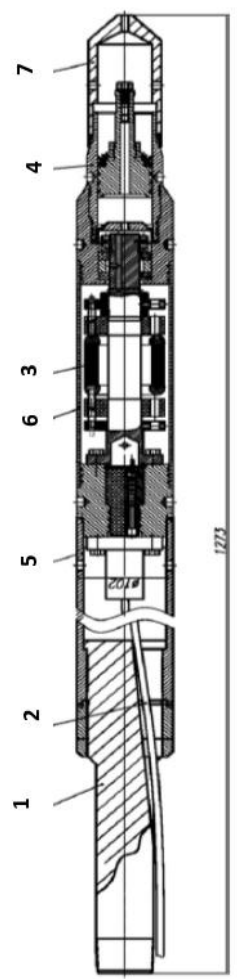

Fig. 2. Downhole Tool PSMS-102 [10].

1 - Reducer NKT-60, 2 - Cable lug, 3 - magnetostrictive radiator, 4 - excess pressure hydrocompensator, 5 - tool housing,

6 - magnetostrictive housing, 7 - trip.

In this study, Nigerian crude oil and rock samples were used to conduct experiments on the application of ultrasound to enhance oil recovery. The tests were conducted on a specialised rig which was designed and constructed to mimick a conventional core flooding set up. A model equation showing the relationship between ultrasonic properties and volume of oil recovered was also developed. Finally, analysis of variance was conducted on the result to validate the significance of the study.

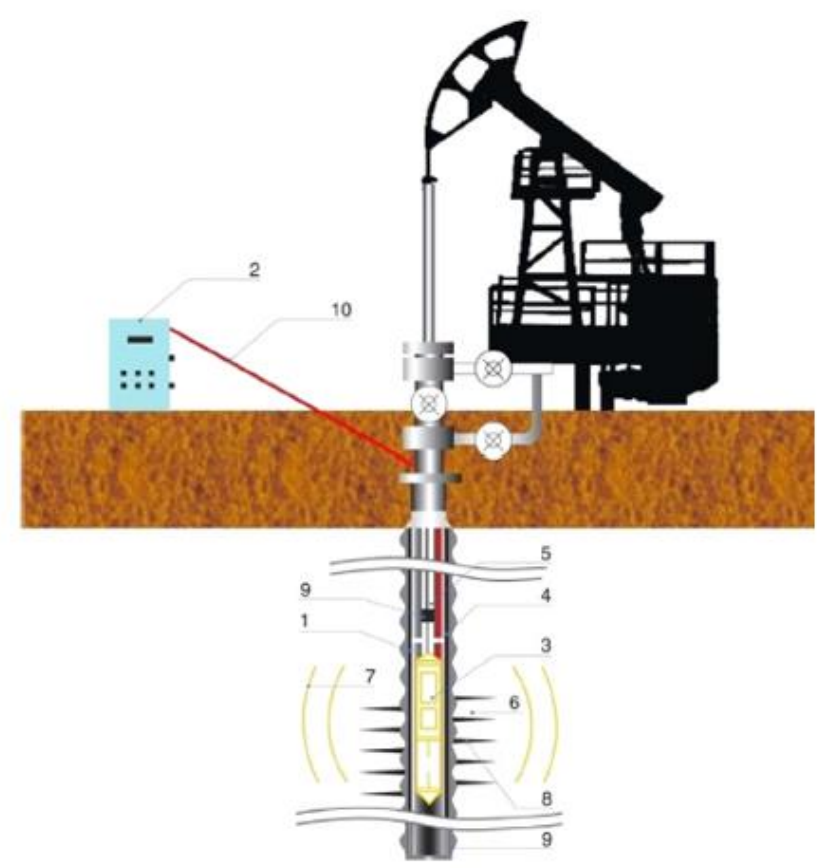

Fig. 3. Wellhead Equipement configuration [10].

1 - Anchor, 2 - ultrasonic generator, 3 - downhole tool, 4 - casing, 5 - tubing, 6 - producing formation, 7 - ultrasonic field, 8 - perforated zone, 9 - sucker rod pump, 10 - downhole tool power cable.

\section{METHODOLOGY}

The method used to achieve the aim of this study was core flood experiment using a special design experimental rig/setup. Core samples from Kerri-Kerri formation in Bauchi Nigeria and crude oil sample form Niger-Delta Nigeria were used to carry out the experiment. The geological epoch of the Kerri-Kerri formation is Palaeocene [11]. According to [12], the Kerri-Kerri basin results from subsequent extension of E-W Cenozoic.

\section{A. Samples}

The core samples used were cylindrical in shape and a size of 3-inch length and 1-inch diameter. The average porosity and permeability of the core were determined experimentally in the laboratory as 0.31 and $234 \mathrm{mD}$ respectively. While the crude oil sample has viscosity of $4.21 \mathrm{cSt}$ at $35^{\circ} \mathrm{C}$ and ${ }^{\circ} \mathrm{API}$ of 36 .

\section{B. Experimental Procedure}

The experiment was started by saturating the core sample with brine formulated with distilled water and $3 \%$ wt $\mathrm{NaCl}$, the saturation was done using the experimental rig in plate 2. The brine was injected at a pressure of 35 psi for 15 minutes until the core is fully saturated with the brine. The next stage of the experiment was the injection of crude oil at a pressure of $40 \mathrm{psi}$ to displace the brine for another 20 minutes until only crude oil visible in the output flow stream (effluent flow). This stage of the experiment was carried out to establish the initial oil and water saturations.

After the establishment of the initial conditions, water flooding process was performed by injecting water at an inlet pressure of 50 psi to displace the oil in the core sample. At the end of the water flooding process the following information were recorded. 
1. Volume of effluent collected.

2. Effluent flow rate.

3. Percentage/volume of oil in the effluent collected.

Another experiment was then carried out with the introduction of ultrasound energy to augment the water flooding process. The oil saturated core sample was irradiated with ultrasound energy for a given time and then followed by water injection/water flooding and the above stated information were also recorded. The ultrasound frequency was kept constant $20 \mathrm{kHz}$ while the power and time were varied. Response Surface Methodology (RSM) was used to design the experiment, analyze results and develop model equation. Table 1 shows the designed parameters. The picture of the special design experimental rig used for this study is displayed in Fig. 4.

TABLE 1: INDEPENDENT VARIABLES AND THE SELECTED FACTOR LEVELS

\begin{tabular}{ccccc}
\hline \multicolumn{4}{c}{ Factor levels of code } & \\
\hline & Code & $\begin{array}{c}\text { Low } \\
\text { level }\end{array}$ & $\begin{array}{c}\text { Intermediate } \\
\text { level }\end{array}$ & $\begin{array}{c}\text { High } \\
\text { level }\end{array}$ \\
\cline { 2 - 5 } & & -1 & 0 & +1 \\
\hline Power (W) & $\mathrm{A}$ & 100 & 300 & 500 \\
Time (min) & $\mathrm{B}$ & 5.00 & 12.50 & 20.00 \\
\hline
\end{tabular}

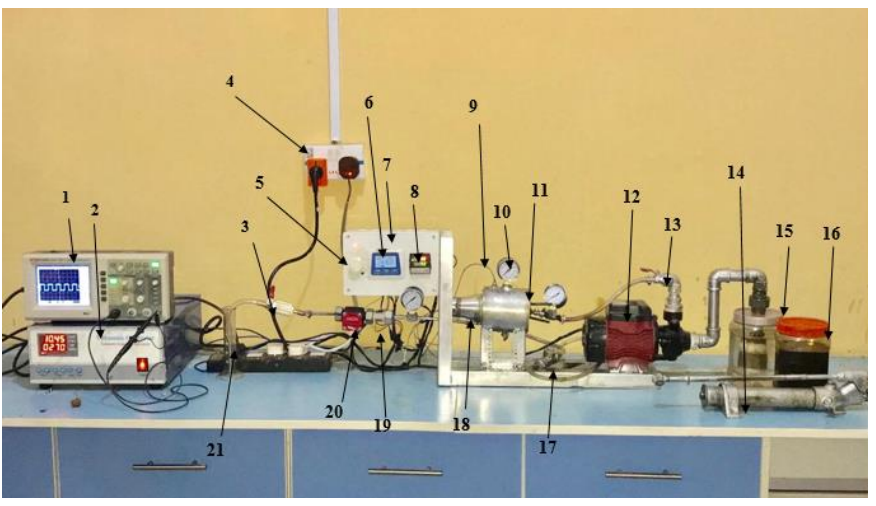

Fig. 4. Complete experimental setup:

1 - oscilloscope, 2 - ultrasound generator, 3 - back pressure regulator, 4 - power supply, 5 - pump control switch, 6 - flow display; 7 - control panel; 8 - temperature controller; 9 - thermocouple; 10 - pressure gauge; 11 - core holder; 12 - suction pump; 13 - control valve;

14 - hand pump; 15 - water/brine container; 16 - crude oil container; 17 - check valve; 18 - transducer; 19 - temperature sensor; 20 - flow sensor; 21 - effluent collector.

\section{RESULT AND DISCUSSION}

After the experiments were run successfully for both waterflooding and waterflooding + ultrasound energy, Table 2 presents the volume of oil present in the effluent collected after water flooding only.

TABLE 2: VOLUME OF OIL IN THE EFFLUENT COLLECTED FOR

\begin{tabular}{ccccc}
\multicolumn{5}{c}{ WATERFLOODING } \\
\hline S/No. & $\begin{array}{c}\text { Sample } \\
\text { name }\end{array}$ & $\begin{array}{c}\text { Total vol. of } \\
\text { effluent } \\
(\mathrm{ml})\end{array}$ & $\begin{array}{c}\text { Vol. of oil in } \\
\text { the effluent } \\
(\mathrm{ml})\end{array}$ & $\begin{array}{c}\text { Vol. \% of } \\
\text { oil in the } \\
\text { effluent }\end{array}$ \\
\hline 1 & $\begin{array}{c}\text { 1- water } \\
\text { injection } \\
\text { only }\end{array}$ & 69 & 2.5 & 3.57 \\
\hline
\end{tabular}

The experiments carried out with the introduction of ultrasound energy to augment the waterflooding process shows an increment in the volume of oil in the effluent produced. Table 3 shows the randomized ultrasound variables (Power and Time) and the corresponding response (volume of oil in the produced effluent) as obtained from the RSM design.

TABLE 3: VOLUME OF OIL IN THE EFFLUENT COLLECTED FOR WATERFLOODING + ULTRASOUND ENERGY AND THE VARIABLES POWER AND TIME

\begin{tabular}{ccccc}
\hline $\begin{array}{c}\text { Number } \\
\text { of Run }\end{array}$ & $\begin{array}{c}\text { Power } \\
\text { (Watts) }\end{array}$ & $\begin{array}{c}\text { Time } \\
\text { (Minutes) }\end{array}$ & $\begin{array}{c}\text { Volume of oil in } \\
\text { the effluent } \\
\text { produced (ml) }\end{array}$ & $\begin{array}{c}\text { \%vol. of } \\
\text { oil in the } \\
\text { effluent } \\
\text { produced }\end{array}$ \\
\hline 1 & 300 & 12.50 & 3.70 & 5.36 \\
2 & 500 & 5.00 & 3.90 & 5.65 \\
3 & 300 & 12.50 & 3.70 & 5.36 \\
4 & 100 & 5.00 & 2.70 & 3.91 \\
5 & 300 & 12.50 & 3.70 & 5.36 \\
6 & 300 & 12.50 & 3.70 & 5.36 \\
7 & 100 & 12.50 & 3.40 & 4.93 \\
8 & 300 & 12.50 & 3.70 & 5.36 \\
9 & 300 & 5.00 & 3.10 & 4.49 \\
10 & 500 & 20.00 & 5.10 & 7.39 \\
11 & 100 & 20.00 & 4.10 & 5.94 \\
12 & 300 & 20.00 & 4.40 & 6.38 \\
13 & 500 & 12.50 & 4.50 & 6.52 \\
\hline
\end{tabular}

The effluents collected were allowed to separate under gravity for 36 hours, plate 3 shows the pictures of some effluent collected. Visual inspection of the effluent shows that ultrasound energy can form a partial emulsion of an oilwater mixture, and this can bring about reduction in capillary forces.

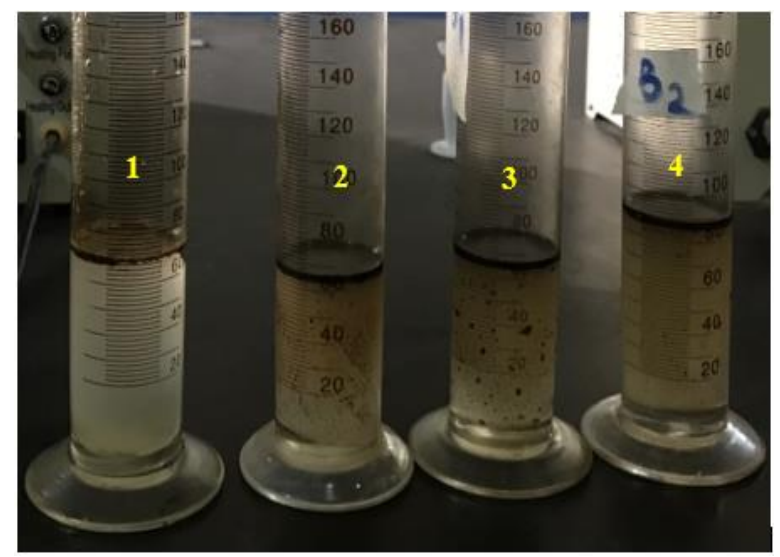

Fig. 5. Some effluent collected.

Analysis of variance (ANOVA) was used to analyze the result obtained. Table 4 shows the ANOVA Table for the variable factors and the response and Table 5 shows the coefficients of variability and determination for the response.

TABLE 4: ANOVA TABLE FOR THE RESPONSE VOLUME AND VARIABLES

\begin{tabular}{cccccc}
\multicolumn{7}{c}{ POWER AND TIME } \\
\hline Source & $\begin{array}{c}\text { Sum of } \\
\text { Squares }\end{array}$ & df & $\begin{array}{c}\text { Mean } \\
\text { Square }\end{array}$ & F value & $\begin{array}{c}\text { p-value } \\
\text { Prob }>\text { F }\end{array}$ \\
\hline Model & 4.54 & 5 & 0.91 & 3687.58 & $\begin{array}{c}<0.0001 \\
\text { significant }\end{array}$ \\
A-Power & 1.82 & 1 & 1.82 & 7368.90 & $<0.0001$ \\
B-Time & 2.54 & 1 & 2.54 & 10292.10 & $<0.0001$ \\
AB & $1.000 \mathrm{E}-002$ & 1 & $1.000 \mathrm{E}-002$ & 40.60 & $<0.0004$ \\
$\mathrm{~A}^{2}$ & 0.14 & 1 & 0.14 & 572.03 & $<0.0001$ \\
B $^{2}$ & $1.847 \mathrm{E}-003$ & 1 & $1.847 \mathrm{E}-003$ & 7.50 & $<0.0290$ \\
Residual & $1.724 \mathrm{E}-003$ & 7 & $2.463 \mathrm{E}-004$ & & \\
Lack of Fit & $1.724 \mathrm{E}-003$ & 3 & $5.747 \mathrm{E}-004$ & & \\
Pure Error & 0.000 & 4 & 0.000 & & \\
Cor Total & 4.54 & 12 & & & \\
\hline
\end{tabular}


From the ANOVA Table (Table 4) the model F-value of 3687.58 implies the model is significant. Values of "Prob > $\mathrm{F}^{\prime \prime}$ less than 0.0500 indicate model terms are significant. In this case A, B, AB, A2, B2 are significant model terms. Values greater than 0.1000 indicate the model terms are not significant.

TABLE 5: COEFFICIENTS OF VARIABILITY AND DETERMINATION FOR THE

\begin{tabular}{cc}
\multicolumn{3}{c}{ RESPONSE } \\
\hline Std. Dev. & 0.016 \\
R-Squared & 0.9996 \\
Mean & 3.82 \\
Adj R-Squared & 0.9993 \\
C.V. \% & 0.41 \\
Pred R-Squared & 0.9974 \\
PRESS1 & 0.012 \\
Adeq Precis1ion & 225.097 \\
\hline
\end{tabular}

From Table 5, the "Predicted R-Squared" of 0.9974 is in reasonable agreement with the "Adjusted R-Squared" of 0.9993. Adeq Precision measures the signal to noise ratio. A ratio greater than 4 is desirable. Therefore, a ratio of 225.097 indicates an adequate signal.

The developed model equation for the response "volume of oil in the produced effluent" and the variables "power, time" at constant ultrasound frequency of $20 \mathrm{kHz}$ is given by Equation 1.

$$
\begin{aligned}
& V=2.25359-2.21264 \mathrm{E}-004 \mathrm{P}+0.085172 \mathrm{~T}- \\
& 3.33333 \mathrm{E}-005 \mathrm{P} \mathrm{T}+5.64655 \mathrm{E}-006 \mathrm{P}^{2}+ \\
& 4.59770 \mathrm{E}-004 \mathrm{~T}^{2}
\end{aligned}
$$

Since the total volume of effluent collected is $69 \mathrm{ml}$, then the model equation for the percentage volume of oil in the produced is effluent is given by Equation 2.

$$
\begin{aligned}
& \% \mathrm{~V}=3.26608-3.20673 \mathrm{E}-004 \mathrm{P}+0.12344 \mathrm{~T}- \\
& 4.83092 \mathrm{E}-005 \mathrm{PT}+8.18341 \mathrm{E}-006 P^{2}+ \\
& 6.66333 \mathrm{E}-004 T^{2}
\end{aligned}
$$

where $\mathrm{V}$ is the volume in the total fluid produced (effluent), $\mathrm{P}$ ultrasound powerand T irradiation time. Fig. 6 shows the contour and 3D plots for the response and the variables.

Both the ultrasound Power and irradiation time have positive impact on the volume oil produced. In other words, increase in power and time result to an increase in oil recovery as shown in Fig. 6.

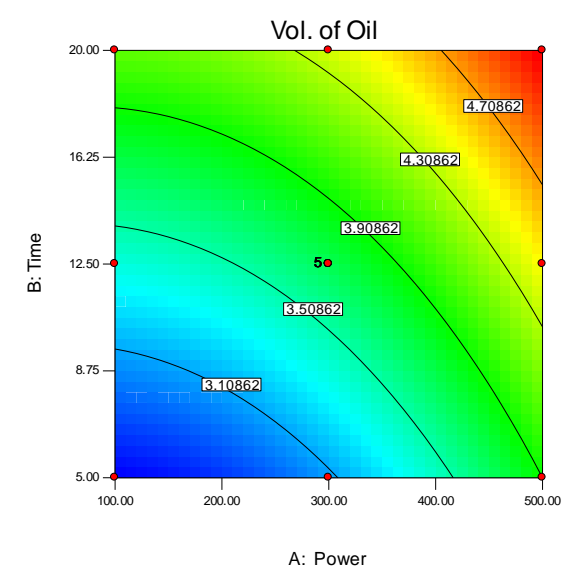

(a)

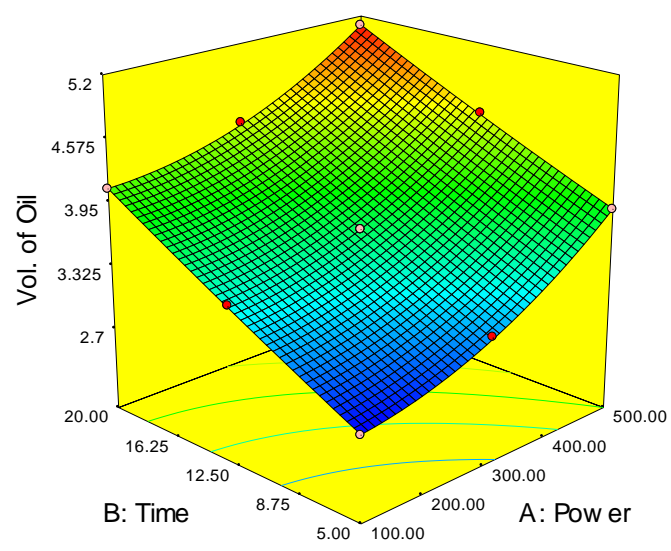

(b)

Fig. 6. (a) contour plot for the response and variables (b) $3 \mathrm{D}$ plot for the response and variables

\section{CONCLUSION}

The outcome of this study has demonstrated that ultrasound energy is effective in mobilizing residual oil during waterflooding. And it was observed from the study that the ultrasound power is the most significant factor in the recovery of oil. The discovered factors that brought about the increase in the oil recovery from the application of ultrasound are increase in temperature and pressure, capillary pressure and viscosity reduction, peristaltic movement of fluid etc. further study is recommended using reservoir rocks with different lithologies to investigate the effect of rock properties on the ultrasound energy performance.

\section{ACKNOWLEDGEMENT}

We wish to acknowledge the Tertiary Education Trust Fund (TETFund) Nigeria for funding this study through its institution Base Research (IBR) Grant. Grant No. ATBU/DVC/Acad/076.

\section{REFERENCE}

[1] Hassan, U., Ajienka, J., \& Sulaiman, A. (2019). Evaluating the performance of ultrasound energy on improved oil recovery using MATLAB reservoir simulation toolbox (MRST). Academic JournalJournal of Petroleum and Gas Engineering, 87-100.

[2] Aurel, C. (1992). Applied Enhanced Oil Recovery. New Jersey: Prentice-Hall Inc ISBN-10:0130442720 and 13:978-0130442727.

[3] Tarek, A. (2010). Reservoir Engineering Handbook. Houston, Texas: Gulf Professional Publishers.

[4] Muhammad, M., \& Mahmoud, M. (2012). Conventional Versus Electrical Enhanced Oil Recovery: a review. Journal of Petroleum Exploration Production Technology: Springer, 157-167.

[5] Vladimir, O. A., Anna, V. A., Igor, B. E., \& Timothy, J. M. (2013). Ultrasonic technology for enhanced oil recovery from failing wells and the equipment for its implementation. Elsevier sonochemistry, 12891295.

[6] Alhomadhi, E., Amro, M., \& Almobark, M. (2014). Experimnetal Application of Ultrasound Waves to Improve Oil Recovery During Waterflooding. Journal of King Saud Univeristy-Engineering Sciences Elsevier, 103-110.

[7] Naderi, K., \& Babadagli, T. (2010). Influence of Intensity and Frequency of Ultrasonic Waves on Capillary Interaction and Oil Recovery from Different Rock Types. Ultrasonics Sonochemistry, Elsevier, 500-508.

[8] Arabzadeh, H., \& Amani, M. (2017). Application of Novel Ultrasonic Technology to Improve Oil Recovery with an Environmental 
Viewpoint. Journal of Petroleum and Environmental Biotechnology 7: 323: DOI: 10.4172/2157-7463.1000323.

[9] Abdulfatah, H. K. (2018). Application of Ultasonic waves in Enhancing Oil Recovery in Secondary Recovery Phase. Society of Petroleum Engineers Annual Technical Conference and Exhibition, Dallas, Texas 24-26 September: SPE - 104031 - STU.

[10] Mullakaev, M. S., Abramov, V. O., \& Abramov, A. V. (2015) Development of ultrasonic equipment and technology for well stimulation and enhanced oil recovery. Journal of Petroleum Science and Engineering-Elsevier, 201-208.

[11] Hamza, H., and Hamidu, I. (2011). Hydrocarbon resource potential of the Bornu Basin Northeastern Nigeria. Global journal of geological sceinces vol. 10 no. 1 201271-84, 71-84.

[12] Odedede, O., \& Adaikpah, E. O. (2011). Sequence stratigraphic analysis of the Gombe sandstone and lower kerri-kerri formation exposed around Fika-Potiskum, upper Benue trough, Nigeria: A consideration for petroleum reservoir indicators. Indian journal of science and technology vol. 4 no. 5, 492-498. http://doi.org/10.17485/ijst/2011/v4i5.13. 